\title{
FUTURE SPECIALISTS' PREPARATION FOR TOXIC COMMUNICATION IN PROFESSIONAL TRAINING
}

\author{
Стаття присвячена актуальній проблемі \\ підготовки майбутніх фрахівців до продук- \\ тивного професійного спілкування в соці- \\ альній роботі, зокрема до подолання викли- \\ ків токсичної комунікації. Автор визначає \\ феномен «токсичне спілкування», причини \\ i фоактори, що його провокують. Наве- \\ дені переконливі аргументи викривають \\ необхідність спеціальної підготовки до \\ організації есрективної взаємодії з різними \\ категоріями клієнтів, особливо схильними \\ до токсичної комунікації, вироблення пози - \\ тивної мотивації до підтримання власноі \\ емоційної стійкості, навичок подолання \\ деструктивного спілкування, фрормування \\ професійно-комунікативної компетентно- \\ сті тощо. \\ У публікації охарактеризовано різні види \\ токсичного спілкування, їх сутність та осо- \\ бливості. Автор привертає увагу до акту- \\ альної і занадто поширеної нині токсичної \\ позитивності, що необгрунтовано закли- \\ кає оріксуватися на позитивних аспектах \\ життя та емоціях, ігнорувати складні та \\ неприємні переживання. \\ Підкреслено роль толерантного став- \\ лення як складника професійно-комуні- \\ кативної компетентності майбутніх \\ фахівців із соціальної роботи, що працю- \\ ватимуть із клієнтами у складних жит- \\ тєвих обставинах, в умовах ненормованої \\ в часі, напруженої взаємодії, яка потребує \\ значних особистих ресурсів фрахівця та \\ вичерпує їх. Попередити останнє можна \\ тільки шляхом постійного вдосконалення \\ своїх знань та вмінь, зокрема антиманіпу- \\ лятивних. \\ Автор статті висвітлює поняття \\ «токсичний комунікант», його типові харак- \\ теристики, природу токсичності, схиль- \\ ність таких осіб до маніпулятивного спіл- \\ кування тощо. Водночас виокремлена низка \\ найпоширеніших помилок фрахівців із соціаль- \\ ної роботи у процесі токсичної комунікації, \\ яких можна уникнути за умови своєчасного \\ і спеціального навчання. \\ Задля протидії профресійному вигоранню \\ соціальних працівників у ситуації некон- \\ структивної взаємодії з колегами та клієн- \\ тами автор пропонує алгоритм подолання \\ токсичного спілкування.
}

к.пед.н.,

доцент кафедри соціальної педагогіки і соціальної роботи

Університет Григорія Сковороди

в Переяславі
Ключові слова: токсичне спілкування, соціальна робота, професійно-комунікативна компетентність, підготовка фрахівців із соціальної роботи.

The article is devoted to the actual problem of future specialists' training for productive professional communication in social work, in particular to overcoming the challenges of toxic communication. The "toxic communication" phenomenon, the causes and factors that provoke it are identified by the author. These convincing arguments reveal the need for special training to organize effective interaction with various categories of clients, especially those prone to toxic communication, developing positive motivation to maintain their own emotional stability, skills to overcome destructive communication, professional and communicative competence.

Different types of toxic communication, their nature and features are described in the publication. The author draws attention to the current and too widespread nowadays toxic positivity, which unreasonably calls to focus on the positive aspects of life and emotions, ignoring the complex and unpleasant experiences.

The role of tolerant attitude to future social workers' component of professional and communicative competence, who will work with clients in difficult life circumstances, in conditions of unregulated time interaction, which requires significant personal resources and exhausts them, is emphasized. The last latter can be prevented only by constantly improving their knowledge and skills.

The concept of "toxic communicator", its typical characteristics, the nature of toxicity, the tendency of such persons to manipulative communication etc. is covered in the author's article. At the same time, a number of the most common socia workers' mistakes in the process of toxic communication, which can be avoided with timely and special training is selected.

The algorithm for overcoming toxic communication in order to counteract the social workers professional burnout in a situation of unconstructive interaction with colleagues and clients is proposed by the author.

Key words: toxic communication, social work, professional-communicative competence, social work specialists' training.
Постановка проблеми. Сучасні вимоги до професійної діяльності фахівців із соціальної роботи на перший план висувають такі особистісні і фахові характеристики, що дають їм змогу ефективно діяти в умовах складного, напруженого, ресурсно обмеженого чи неекологічного спілкування.

Професіоналізм фахівців із соціальної роботи, будучи багатогранним феноменом, об'єднує систему інтегрованих знань, умінь, особистісних та професійно важливих яко- стей, культуру й майстерність, здатність до самовдосконалення. У зв'язку з цим фахова підготовка має орієнтуватися насамперед на формування професійної готовності майбутніх фахівців із соціальної роботи до продуктивної діяльності, заснованої насамперед на спілкуванні, що передбачає високий рівень їхньої професійно-комунікативної компетентності. Професійна готовність визначається як системна сукупність професійних якостей, необхідних для самостійної фахової 
діяльності, що складається з мотиваційного, операційного, орієнтаційного, вольового, емоційно-оцінного, психофізіологічного компонентів. Основними параметрами професійно важливих якостей фахівців із соціальної роботи вважаються характеристики фізичного і психологічного здоров'я, усвідомлення професійного вибору, ціннісні орієнтації особистості (гуманізм, чесність, порядність, справедливість, милосердя), психологічні якості особистості (емпатійність, наполегливість, самодисципліна, великодушність, толерантність, співчутливість, раціональність, старанність) тощо $[4 ; 5 ; 6]$.

Аналіз останніх досліджень і публікацій. Як відомо, формуванню професійної компетентності соціального працівника присвячені роботи А. Белінської, В. Бочарової, О. Карпенко, А. Ляшенка, Г. Попович, В. Сидорова, $€$. Холостової. Окремі аспекти, які стосуються змісту й структури професійно-комунікативної компетентності фахівців різних галузей, розкривають дослідження Л. Галікової, Д. Годлевської, Т. Доловової, В. Зикової, С. Петрушина. Водночас особливості підготовки майбутніх фахівців до професійного спілкування досліджують Т. Алексєєва, Н. Волкова, Л. Дарійчук, В. Пасинок, Л. Савенкова.

Як і Є. Зеєр, А. Панфілова, А. Хуторський, ми розуміємо професійну компетентність фахівців із соціальної роботи через призму фахової діяльності, що оптимізує ії, реалізується за допомогою відповідних знань, умінь, навичок та детермінується низкою індивідуально-особистісних характеристик, репрезентується через професійно-комунікативну компетентність [4].

Постановка завдання. Метою статті $€$ дослідження проблеми підготовки майбутніх фахівців до продуктивного професійного спілкування в соціальній роботі, зокрема до подолання викликів токсичної комунікації.

Виклад основного матеріалу дослідження. Професійна діяльність фахівців із соціальної роботи тісно пов'язана з численними фаховими ситуаціями, пов'язаними з токсичним спілкуванням, що супроводжує проблеми, конфлікти, біди насамперед у житті клієнтів, що потрапили у складні життєві обставини, а також колег, які неправильно реагують на робочі питання. За таких умов люди постійно скаржаться і сваряться, маніпулюють та звинувачують, зокрема соціальних працівників чи один одного.

Традиційно науковці виділяють низку видів токсичного спілкування, які руйнують стосунки між людьми. Серед них слід назвати такі:

- докір (словесний напад) - часто це порада щодо минулого (типові словесні формули «що ж ти», «даремно ти», «треба було», «чому ти не», «я ж казав», «я так і знав» тощо);
- виправдування - аргументація власних дій (чи бездіяльності) переважно шляхом докору задля «обеззброєння» опонента, звинувачення його, схиляння до самокритики, пояснення («це не я», «це тому що»);

- сарказм (насмішка) - різке, жорстке висміювання чогось, підкреслювання чийогось недоліку, вади на основі контрасту, перебільшення та негативного оцінювання;

- ігнорування - нехтування, брак уваги до чогось тощо [1; 3].

Одним зі складників токсичного спілкування $є$ тотальний контроль, що передбачає стеження й контролювання за всіма учасниками взаємодії. Такі особи не здатні слухати й чути, з одного боку, перебільшуючи власне значення, а з іншого боку, відчуваючи страх, коли беруть відповідальність на себе, звинувачуючи когось стороннього.

Названі види токсичного спілкування найчастіше використовуються в ситуації конфлікту. У поведінці токсичних комунікантів значне місце посідають негативне світосприйняття і всеохоплююча критика, тобто прагнення все представити в темних тонах, зосереджуватися на негативі в собі та інших, накопичувати образи, претензії, заздрощі, звинувачення, вдаватися до неконструктивного критицизму, відшукувати чужі помилки й нехтувати позитивом.

Тісно пов'язано з цим нетолерантне ставлення до оточуючих, яке допускає некоректні висловлення, злі жарти, сарказм, цинізм тощо. Такі люди інтригують, зневажливо ставляться до клієнтів і колег, особливо нижчих за статусом.

Нерідко занурення в токсичне спілкування зумовлене страхом виходу із зони комфорту, уникненням пізнання нового, змін, небажанням розвиватися, удосконалюватися, працювати над собою, невпевненістю у власних силах, сумнівами в можливості покращити ситуацію тощо.

Токсичний комунікант - це складна у спілкуванні особа, яка має усталений стиль деструктивної комунікації та здатність отруювати стосунки.

Здебільшого такі люди не розуміють, заради чого вони вступають у взаємодію з іншими, мають суперечливі думки й наміри; самостверджуються за рахунок інших відкрито чи латентно; змінюють свою позицію та очікування в ході спілкування; даремно витрачають час і ресурси фахівців із соціальної роботи; перебільшують роль іншої (зокрема, посадової) особи у вирішенні власних проблем. Ознаками токсичного клієнта чи колеги є постійні скарги, пошук і висловлення негативу, критика, крик, емоційні, некоректні висловлення, вороже сприйняття співрозмовника, схильність до суперечок, перекручування почутого, 
уникання прямих відповідей на поставлені запитання, необґрунтовані претензії, обвинувачування й закиди, знецінення людей, їхніх соціальних ролей та дій [1; 3].

Токсичний комунікант має на меті позбавити ресурсу чи знищити емоційно свого співрозмовника, викликаючи у нього почуття провини, низьку оцінку особистих якостей, зниження енергії, постійну рефлексію, негативні емоції тощо. Першим завданням токсичного учасника спілкування $є$ прагнення викликати у співрозмовника емоційну реакцію (вивести із себе), унаслідок якої зникає чи знижується критичність мислення, здатність логічно діяти.

Токсичні комуніканти йдуть на відкритий конфлікт украй рідко, хоча серед них є й агресивні особи. Причинами появи такої поведінки можуть бути не тільки низькі комунікативні знання та вміння, але й наслідки сімейного виховання, відсутність моделей правильного спілкування, особисті проблеми, нездатність керувати своїми емоціями, контролювати власну поведінку тощо.

Негативний вплив токсичних працівників на діяльність соціальної служби полягає у зниженні її продуктивності, пришвидшенні плинності кадрів, створенні нездорової, напруженої атмосфери в колективі через вербальну агресію, психологічне насильство, конфлікти, інтриги, плітки, знецінення, привнесені токсичними комунікантами.

Окремо слід сказати про токсичну позитивність, що скеровує на зосередження тільки на позитивних аспектах життя та емоціях, ігнорування складних і неприємних переживань. Такий підхід примітивізує стосунки між людьми й розуміння реальних проблем, ослаблює опір стресу, створює оманливий ефект «теплої ванни».

Дослідники називають такі типи токсичних комунікантів:

- жертва - «хронічні скаржники», тобто особи, в житті яких усе погано (погода, оточення, справи, робота тощо), що характеризуються поганим настроєм, ображеністю, агресивністю; її головне комунікативне завдання полягає в тому, щоби поділитися негативом, сумом, незадоволенням, знайшовши свого «чуйного слухача»;

- маніпулятор - комунікант, який змушує співрозмовника почуватися винним через брак уваги до своєї особи, недостатність інтересу до його справ, слів, бажань; така людина перекладає відповідальність за останні на когось, апелюючи до професійних обов'язків, порушуючи особисті кордони фахівців із соціальної роботи, будить у них почуття провини, сорому тощо;

- ненаситний - комунікант, якому замало уваги (скільки б її не було), що зумовлене його низькою самооцінкою, потребою в чиїйсь похвалі, підтримці й схваленні; подібні люди вимагають чужих емоцій та енергії, замикання розмови лише на своїй персоні, перетворюючись на маніпулятора;

- заздрісник - той, кому замало всього у приватному житті й професії, хто вважає себе несправедливо обділеним і ображеним (девіз «добре вам», «пощастило вам»); такі токсичні комуніканти змушують інших ділитися з ними, відбирають час і сили візаві, вдаються до злих зауважень, пліток, насмішок для зниження самооцінки співрозмовника;

- панікер - тривожна особа, яка сіє паніку, страх, занепокоєння, заражаючи оточуючих нервозністю, сумнівами у власній компетентності, розхитуючи віру у свої сили, зменшуючи здатність об'єктивно оцінювати й вирішувати ситуацію внаслідок її емоційного тиску; у результаті такого спілкування у фахівця із соціальної роботи виникає зайва підозрілість, нерішучість, негативізм, поява професійних деформацій;

- привид - той, хто зненацька зникає, тікає від людей, реальних дій і знову повертається за найперших труднощів чи потреб;

- доросла дитина - особа, яка постійно вимагає допомоги, вказівок, підтримки від інших, водночас перекладаючи відповідальність за власне життя на когось;

- нарцис - егоцентрована людина, зорієнтована лише на власні потреби та інтереси, зацікавлена максимально скористатися чиїмись можливостями й ресурсами;

- вічний критик - той, хто постійно суб'єктивно, неконструктивно оцінює та критикує інших;

- підбурювач - особа, яка «зіштовхує людей лобами», розсварює, роз'єднує їх, вносить протистояння в будь-яке середовище тощо [2].

Узагальнюючи, маємо відзначити кілька традиційних характеристик токсичного комуніканта, а саме агресивність, нарцисичність, некоректність, ригідність, заздрісність, ревнивість, озлобленість.

Услід за Марком Черноффим назвемо найтиповіші різновиди токсичних взаємин, які треба долати, а саме це відносини, що ініційовані й керовані однією людиною; покликані «заволодіти» вами; засновані на взаємозалежності; спираються на ідеалізовані очікування; передбачають виправдування теперішніх проблем колишніми провинами; містять щоденну неправду; не дають змоги відновити довіру, пробачити; проявляють пасивну агресію, яка витісняє спілкування; базуються на провідній ролі емоційного шантажу; відсуваються на задній план [3].

Поширеними помилками фахівців із соціальної роботи в ситуації токсичного спілкування вважаємо виправдування, замовчу- 
вання, спроби віджартовуватися, некритично сприймати інформацію, довіряти їй, енергетично «відкриватися». Токсичні клієнти та колеги нерідко провокують у фахівців із соціальної роботи синдром емоційного вигоряння, виражений стомленістю, дратівливістю, негативним сприйняттям життя.

Правильна комунікативна поведінка - це здатність відкрито говорити, пояснювати, що саме є дискомфортним у стосунках з людиною, завдає болю; не звинувачувати, але пояснювати свої почуття; уміти окреслювати кордони, чітко говорити, як із вами можна поводитися; припиняти чи максимально обмежувати стосунки з токсичною людиною, яка не хоче змінювати свою поведінку; не спілкуватися з тими, хто шкодить. У зв'язку з цим для фахівців із соціальної роботи корисним має стати вислів «Не буває токсичних людей, бувають погані дистанції».

Важливо знати ознаки включення до токсичного спілкування, що проявляються спектром таких відчуттів: надмірна емоційність в оцінюванні ситуації, неприємне враження від співрозмовника, знесилення після взаємодії з ним, гостре почуття провини, прагнення до постійного вдосконалення зробленого, неготовність сказати «ні», нехтування власними інтересами і бажаннями, підозрілість, прискіпливість. Необхідно зауважити, що токсичне спілкування спричиняється обома його учасниками, оскільки один із комунікантів погоджується терпіти отруйну поведінку свого співрозмовника.

Алгоритм протидії токсичному спілкуванню у професійній діяльності фахівців із соціальної роботи передбачає таке:

1) формування адекватних очікувань щодо спілкування (усвідомлення загроз від токсичного співрозмовника, підготовка до психологічного самозахисту);

2) організація коректної, конструктивної взаємодії (сприяють цьому такі формули: «я відчуваю», «я розумію», «я поважаю вашу думку»);

3) уміння вибудувати власні кордони, свою зону комфорту, вимагати їх дотримуватися;

4) здатність встановлювати дистанцію (фізичну та психологічну);

5) готовність говорити «ні», зокрема відмовляти без пояснень, не сплутувати професійне та особисте життя;

6) уміння вчасно припиняти свою діяльність, не мати прагнення безкінечно її вдосконалювати;

7) здатність закінчувати спілкування, залишатися при своїй думці, звільнятися від неприємних стосунків $[1 ; 4]$.

Підготовка майбутніх фахівців із соціальної роботи до протидії токсичному спілкуванню у професійній діяльності покликана допомогти оволодіти низкою відповідних комунікативних прийомів, серед яких слід назвати такі:

- розуміння прихованого наміру завдяки збереженню об'єктивного, неемоційного, раціонального сприйняття ситуації, розкриттю прихованих комунікативних намірів та інтересів співрозмовника;

- нестандартна поведінка, представлена неочікуваними, нешаблонними діями мовця;

- витримання паузи для сповільнення темпу, осмислення ситуації, прийняття зваженого рішення, зняття напруги;

- постійне уточнення як інструмент перехоплення комунікативної ініціативи, керування комунікацією через ланцюжок запитань, які виводять токсичного комуніканта з рівноваги, руйнують його заготовлений сценарій;

- удавана згода - неконфронтаційний прийом вигравання додаткового часу на прийняття рішення, консультування, м'якої відмови («так, але»);

- амортизація - спосіб без суперечки задовольняти глибинні психологічні потреби токсичного комуніканта (потреби його внутрішньої дитини чи батька) шляхом спонукання до конструктивного діалогу;

- увага до власної тілесності, що передбачає врахування сигналів невербального спілкування, зокрема реакцій свого тіла (підвищення тиску, збільшення частоти серцевих скорочень, зміни в диханні, потіння долонь тощо), контролю за ними й опанування себе $[1 ; 6]$.

Важливим компонентом конструктивної поведінки в умовах токсичного спілкування є сформованість у фахівців із соціальної роботи вмінь правильного виходу з такої комунікативної ситуації. Традиційно говорять про здатність звільнятися від негативних емоцій (наприклад, за допомогою арттерапії); максимально концентруватися (зосереджуватися на думках, словах, предметі мовленні); заспокоюватися, контролюючи дихання, розслаблювати власне тіло (гімнастика, м'язова релаксація, відпочинок на свіжому повітрі); дотримуватися позитивного стилю мислення, організовувати змістовне дозвілля (читання, перегляд фільмів, живопису, слухання музики).

Необхідним стає вміння долати токсичну позитивність шляхом вироблення здатності відчувати весь спектр емоцій, а саме позитивних і негативних, дбати про свій психічний стан, здоровий спосіб життя тощо.

Висновки 3 проведеного дослідження. Отже, токсичні комуніканти не тільки не готові до конструктивного спілкування, але й не підтримують нормальні взаємини з колегами, порушують доброзичливу атмосферу в колективі, транслюють негативні моделі поведінки й професійного спілкування. Фахівці із 
соціальної роботи часто змушені працювати з людьми, що мимоволі вдаються до токсичної комунікації через складні життєві ситуації, проблеми й поганий психологічний стан. Важливо розрізняти поодинокі прояви комунікативної токсичності, рівень якої можна і треба м'яко знижувати шляхом привернення уваги людини до ї̈ поведінки, висловлень, емоцій, пропонування психологічної підтримки, емпатійного слухання тощо. Водночас соціальні працівники повинні бути готовими до агресивної моделі поведінки у процесі токсичної комунікації, уміти вчасно застосовувати відповідні комунікативні прийоми, психологічний захист, які збережуть власне здоров'я фахівця, попередять його професійні деформації, а також сприятимуть створенню продуктивної, доброзичливої атмосфери у взаєминах між колегами та клієнтами.

\section{ЛITEРATУРA:}

1. Зімовін О., Зімовіна Т. «Токсичний» відвідувач: як спілкуватися. URL: https://i.factor.ua/ukr/journals/ ms/2018/february/issue-2/article-34180.html.

2. Панасюк Л. 6 типів токсичних людей, яких краще не брати в своє оточення. URL: https:// life.pravda.com.ua/society/2018/12/16/234686.

3. Періг І. Як розпізнати «токсичні» відносини? Матеріали XX наукової конференції. Тернопіль : ТНТУ ім. І. Пулюя, 2017. С. 273-274.

4. Перхайло Н. Сучасні комунікативні технології в соціальній роботі : навчально-методичний посібник. Переяслав-Хмельницький : ФОП Домбровська Я., 2018. 111 c.

5. Перхайло Н. Профрілактика професійного вигоряння у соціальній роботі : навчально-методичний посібник. Переяслав-Хмельницький : ФОП Домбровська Я., 2018. 143 с.

6. Філоненко М. Психологія спілкування : підручник. Київ : Центр навчальної літератури, 2008. 224 с. 